


\section{ENVIRONMENT AND DEVELOPMENT ECONOMICS}

published in association with the Beijer Institute of Ecological Economics,

Royal Swedish Academy of Sciences

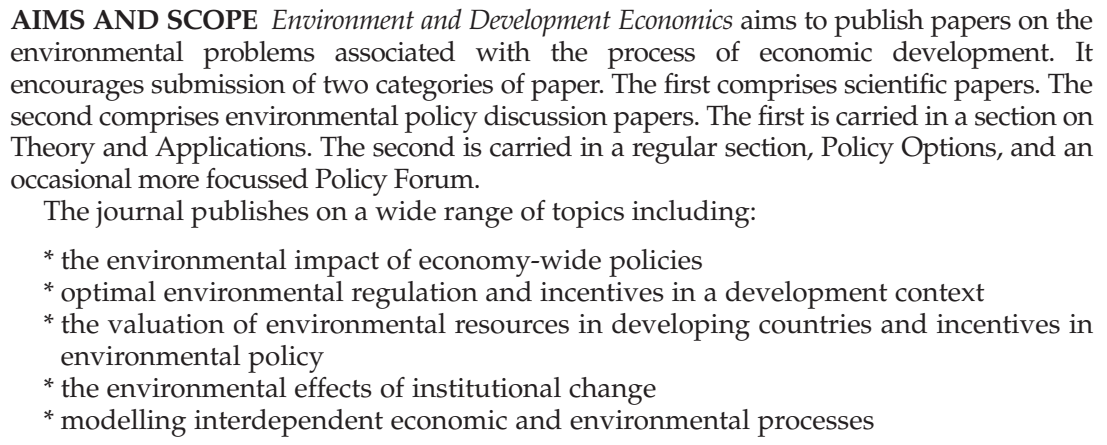

SUBSCRIPTIONS Environment and Development Economics (ISSN 1355-770X) is published bimonthly in February, April, June, August, October and December. Six parts form a volume. The subscription price (excluding VAT), which includes print and electronic access, and postage, of Volume 21 in 2016 is $£ 370$ (\$600 in the USA, Canada and Mexico), for institutions and $£ 60$ (\$97 in the USA, Canada and Mexico) for individuals ordering direct from the publisher and certifying that the journal is for their personal use. The electronic-only price available to institutional subscribers is $£ 289$ (US\$482 in the USA, Canada and Mexico). Single parts are $£ 66$ (US\$107 in the USA, Canada and Mexico). Prices include delivery by air where appropriate. Orders which must be accompanied by payment, may be sent to a bookseller, subscription agent or direct to the publisher: Cambridge University Press, Journals Fulfillment Department, UPH, Shaftesbury Road, Cambridge, CB2 8BS, UK: or in the USA, Canada and Mexico: Cambridge University Press, Journals Fulfillment Department, 1 Liberty Plaza, Floor 20, New York, NY 10006, USA. EU subscribers who are not registered for VAT should add VAT at their country's rate. VAT registered subscribers should provide their VAT registration number. Japanese prices for institutions are available from Kinokuniya Company Ltd, PO Box 55, Chitose, Tokyo 156, Japan. Special arrangements exist for subscribers in most low-income countries. Apply to: Journals Marketing Department, Cambridge University Press, University Printing House, Shaftesbury Road, Cambridge, CB2 8BS, UK.

Periodicals postage is paid at New York, NY, and at additional mailing offices. POSTMASTER: send address changes in the USA, Canada and Mexico to: Environment and Development Economics, Cambridge University Press, 1 Liberty Plaza, Floor 20, New York, NY 10006, USA.

Copying This journal is registered with the Copyright Clearance Center, 222 Rosewood Drive, Danvers, MA 01923, USA. Organizations in the USA who are also registered with C.C.C. may therefore copy material (beyond the limits permitted by sections 107 and 108 of U.S. Copyright law) subject to payment to C.C.C. of the per-copy fee of $\$ 12.00$. This consent does not extend to multiple copying for promotional or commercial purposes. Code 1355-770X/2016.

ISI Tear Sheet Service, 3501 Market Street, Philadelphia, PA 19104, USA, is authorised to supply single copies of separate articles for private use only.

Organizations authorised by the Copyright Licensing Agency may also copy material subject to the usual conditions.

For all other use, permission should be sought from Cambridge or from the American Branch of Cambridge University Press.

This journal is included in the Cambridge Journals Online service which can be found at http://journals.cambridge.org. For further information on other Press titles access http:/ / www.cambridge.org

ISSN 1355-770X @ Cambridge University Press 


\section{CONTENTS}

SHAIKH M. RAHMAN, ARIEL DINAR and DONALD F.

LARSON The incidence and extent of the CDM across

developing countries

DONATELLA BAIARDI, MATTEO MANERA and MARIO

MENEGATTI The effects of environmental risk on consumption dynamics: an empirical analysis on the Mediterranean countries

MARIANO JAVIER RABASSA and JUAN IGNACIO ZOLOA

Flooding risks and housing markets: a spatial hedonic analysis for La Plata City

CLAUDINE UWERA and JESPER STAGE Individual status quo modelling for a rural water service in Rwanda: application of a choice experiment

LEONARDO BECCHETTI, STEFANO CASTRIOTA and PIERLUIGI CONZO Social capital dynamics and collective action: the role of subjective satisfaction in a common pool resource experiment

GETACHEW NIGATU and ARIEL DINAR Economic and hydrological impacts of the Grand Ethiopian Renaissance Dam on the Eastern Nile River Basin 


\section{ENVIRONMENT AND DEVELOPMENT ECONOMICS}

published in association with the Beijer Institute, Royal Swedish Academy of Sciences

\section{EDITOR}

Eswaran Somanathan, Indian Statistical Institute, Delhi

\section{ASSOCIATE EDITORS}

Allen Blackman, Resources for the Future,

Washington, DC

Carlos Chávez, Universidad de Talca

Susana Ferreira, University of Georgia

George Halkos, University of Thessaly

Louis Hotte, University of Ottawa

Alemu Mekonnen, Addis Ababa University

Katrin Millock, CNRS, Paris School of

Economics

Martin Quaas, Christian-Albrechts-

University of Kiel
Ping Qin, Renmin University of China

Juan Robalino, CATIE and Universidad de

Costa Rica

Elizabeth Robinson, University of Reading Elisabetta Strazzera, University of Cagliari Anant Sudarshan, Energy Policy Institute at Chicago, India

Mahmud Yesuf, American University

\section{ASSISTANT EDITOR}

Dimi Xepapadeas

\section{EDITORIAL BOARD}

Francisco Alpízar, Tropical Agricultural and Higher Education Center, Costa Rica, Kenneth Arrow, Stanford University, Edward B. Barbier, University of Wyoming, Lucas Bretschger, Center of Economic Research at ETH Zurich, Juan-Camilo Cárdenas, Universidad de los Andes, Bogotá, Margaret Chitiga, University of Pretoria, Maria Cunha e Sá, Universidade Nova de Lisboa, Partha Dasgupta, Cambridge University, Salvatore Di Falco, University of Geneva, Hossein Farzin, University of California, Davis, Carl Folke, Beijer Institute, Gérard Gaudet, Université de Montréal, Rashid Hassan, University of Pretoria, Jikun Huang, Chinese Academy of Sciences, Razack Lokina, University of Tanzania, Karl-Göran Mäler, Beijer Institute, Jane W. Kabubo-Mariara, University of Nairobi, Subhrendu Pattanayak, Duke University, Charles Perrings, Arizona State University, Rüdiger Pethig, University of Siegen, Karen Pittel, Ifo Institute for Economic Research and University of Munich, Eftichis Sartzetakis, University of Macedonia, Mordechai Shechter, University of Haifa, V. Kerry Smith, Arizona State University, Jeff Vincent, Duke University, Anastasios Xepapadeas, Athens University of Economics and Business, Jintao Xu, Peking University, Aart de Zeeuw, Tilburg University and Beijer Institute, David Zilberman, University of California, Berkeley. 